\title{
Impact of Frontline Demonstrations on Productivity and Profitability of Blackgram (Vigna mungo) in Kota District of Rajasthan, India
}

\author{
K.M. Sharma*, M.C. Goyal, Mahendra Singh and Anil Kumar Sharma \\ Krishi Vigyan Kendra, Borkhera, Kota (Rajasthan)-324001, India \\ *Corresponding author
}

\begin{tabular}{|c|}
\hline Keywords \\
\hline $\begin{array}{l}\text { Blackgram, B:C } \\
\text { ratio, Frontline } \\
\text { demonstration, } \\
\text { Technological gap }\end{array}$ \\
\hline Article Info \\
\hline $\begin{array}{l}\text { Accepted: } \\
\text { 07 March } 2019 \\
\text { Available Online: } \\
10 \text { April } 2019\end{array}$ \\
\hline
\end{tabular}

\section{A B S T R A C T}

\begin{abstract}
Blackgram is a major kharif pulse crop in Kota district of Rajasthan, which covers more than 25 percent acreage of kharif sown area of the district. However, average yield of the district varying between 5-7.25 $\mathrm{q} \mathrm{ha}^{-1}$ which can be enhanced up to $10 \mathrm{q} \mathrm{ha}^{-1}$ or more by the adoption of new varieties and recommended agro-techniques. To demonstrate improved production technologies, cluster front-line demonstrations were conducted on blackgram crop by Krishi Vigyan Kendra, Kota, during kharif 2016 to 2018 on 260 farmer fields of the district. Technological interventions demonstrated consists of use of variety Pant urd-31, seed treatment with carbendazim50 WP @ $2.0 \mathrm{~g} / \mathrm{kg}$ seed \& inoculation of Rhizobium \& PSB culture, sowing in $30 \mathrm{~cm}$ rows apart, recommended doses of NP (20-40 $\left.\mathrm{kg} \mathrm{ha}^{-1}\right)$ and zinc sulphate $\left(25 \mathrm{~kg} \mathrm{ha}^{-1}\right)$, weed management by application of imazathapyr 10 SL@550 ml/ha 15-20 DAS and sucking pest management by application of imidacloprid 17.8 SL @ $250 \mathrm{ml} / \mathrm{ha}$. The study of three years data revealed that demonstrated technologies resulted in substantially higher yield of blackgram than that of local check with mean seed yield of $8.37 \mathrm{q} \mathrm{ha}^{-1}$ which represents 39.27 cent yield enhancement over local check $\left(6.01 \mathrm{q} \mathrm{ha}^{-1}\right)$. Demonstrated techniques fetched average net returns of Rs $21345 \mathrm{ha}^{-1}$ with B: C ratio of 2.09 , higher in comparison to local practice (Rs $13627 \mathrm{ha}^{-1}$ with B: C ratio 1.86). An average additional returns of Rs.11484 ha ${ }^{-1}$ was obtained under demonstrated technologies with incremental B: C ratio of 3.05. Yield gap analysis showed average extension gap of $2.36 \mathrm{q} \mathrm{ha}^{-1}$, emphasizes the need for transferring the feasible improved technologies among farmers to bridge the existing extension gap. Technology index in the present study varied between 31.00 to 61.73 per cent and averaged 44.20 per cent.
\end{abstract}

\section{Introduction}

Blackgram is a major kharif pulse crop of the district Kota, area of which increased from mere 21126 ha in kharif 2015 to 98729 ha in kharif 2018. However, average productivity of blackgram in the district is varying between 5.0 to $7.6 \mathrm{q} \mathrm{ha}^{-1}$ during 2016 to 2018
(Anon., 2018). Major factors responsible for low productivity of blackgram in the district includes disturbances in onset and distribution in rainfall, use of old variety seeds, lack of seed treatment \& bio-fertilizer inoculation, inadequate weed management, inadequate $\&$ improper fertilizer and inadequate plant protection measures specially against sucking 
pest. There exist ample scope to enhance the average productivity of blackgram up to $10 \mathrm{q}$ $\mathrm{ha}^{-1}$ or more by the adoption of improved varieties with yellow vein mosaic resistance and recommended agro-techniques. Farmers in the Kota district are using seeds of old varieties i.e. T-9, Krishna and local seeds. These varieties suffer due to yellow vein mosaic disease and produce less number of pods per plant. Yellow vein mosaic transmitted through white flies has been a serious production constraint in blackgram cultivation in India (Singh et al., 2015). Pant urd-31, a yellow vein mosaic resistance variety developed at G.B. Pant university of agriculture \& technology, Pantnagar and has been recommended for cultivation in Rajasthan and other states of India.

Research for improving agricultural productivity does not serve its purpose till it reaches to the farmer's fields. Frontline demonstrations are one of the important dissemination process for transfer of technology and to establish its production potentials on the farmer's field. Therefore, frontline demonstrations were conducted during kharif seasons of the year 2016 to 2018 on selected farmer's fields of the operational area of Krishi Vigyan Kendra, Kota with the objective of exhibiting the performance of improved variety Pant Urd-31 along with cost-effective improved agrotechniques which could be adopted by the farmers for yield enhancement.

\section{Materials and Methods}

Cluster Frontline demonstrations (CFLD's) were conducted under National Food security Mission during kharif seasons of year 2016 to 2018 in 110 ha area on 260 farmers fields covering 13 different villages of operational area of KVK, Kota namely Suhana, Abhaypura, Tahla, Umarhedi, Padasliya, Dungarjya, Bhandahera, Godliyaheri,
Baluhera, Nangalheri, Sohankhera, Haripura and Bagtari. Kota District falls under Agroclimatic Zone-V "Humid South-eastern plain zone" of Rajasthan. The climate in the district is semi arid and moderate. Soils of the study area clay loam in texture with low nitrogen, low to medium phosphorus, high in available potassium and widely deficient in zinc. The area under each FLD's was kept 0.4 to 0.5 ha with farmers practice as control plots. Farmer's for the FLD's were selected based on group meeting taking in to consideration mainly the approachable site and adaptive attitude of the farmers. Technological interventions under demonstration were decided based on technological gap analysis (Table 1). Based on gap analysis, technological interventions demonstrated includes improved variety Pant Urd-31, seed treatment with Carbendazim 50 wp @ 2 g/kg seed \& inoculation with Rhizobium \& PSB cultures, soil treatment with Trichoderma viride @ $2.5 \mathrm{~kg} / \mathrm{ha}$ (mixed with 20-25 kg FYM), sowing at $30 \mathrm{~cm}$. rows spacing, recommended NP (20:40 kg/ha) and zinc @ $25 \mathrm{~kg} / \mathrm{ha}$, weed management by application of Imizathapyr $10 \mathrm{SL} @ 550 \mathrm{ml} / \mathrm{ha}$ at $15-20$ DAS and sucking pest management by spray of Imidacloprid 17.8 SL $250 \mathrm{ml} / \mathrm{ha}$. Selected farmers were provided trainings on advanced agro-techniques for higher productivity of blackgram. Critical inputs decided based on technological gap analysis were provided and other inputs were suggested as per need. Crop was sown during last week of June to second week of July drilled in $30 \mathrm{~cm}$ rows apart.

All steps like site and farmer selection, layout of demonstration, farmer's participation etc. were followed as suggested by Choudhary (1999). Monitoring of CFLD sites were done by periodical visits and needful suggestion were given to the farmers. Field days were also organized at crop maturity to demonstrate the impact of CFLD among other farmers of the area for horizontal spread of 
technologies. The crop was harvested during second fortnight of September. Data related to yield and cost particulars were collected separately for CFLD and farmers practice. The average prices of inputs and outputs commodities prevailed during each year of demonstrations were taken for calculating cost of cultivation, net return and benefit cost ratio. The technology gap, extension gap and technology index were calculated as suggested by Samui et al., (2000).

Technology gap $=$ Potential yield Demonstration yield

Extension gap $=$ Demonstration yield Farmers yield

Technology index $(\%)=($ Technology gap $/$ Potential yield) $\times 100$

\section{Results and Discussion}

The data on average yield (Table 2) reveals that application of demonstrated technologies resulted in substantially higher blackgram yield than that of local check (farmer's practice) during all the three years (2016 to 2018). The average yield of blackgram during three years ranged from 5.74 to $10.35 \mathrm{q} \mathrm{ha}^{-1}$ under demonstrated technologies as against 4.16 to $7.25 \mathrm{q} \mathrm{ha}^{-1}$ under farmers practices (local check). Higher yield observed during kharif 2017 might be due to favorable rainfall conditions. Yield performance during kharif 2018 was recorded lower due to heavy rainfall at flowering as well as maturity phase which caused loses by water logging conditions. Three years pooled data show that demonstrated technologies recorded mean yield of $8.37 \mathrm{q} \mathrm{ha}^{-1}$ which represents 39.27 per cent yield enhancement over local check (6.01 $\left.\mathrm{q} \mathrm{ha}{ }^{-1}\right)$. The higher productivity of blackgram under demonstration in comparison to farmer's local practice could be ascribed mainly to the use of YMV resistant variety
Pant Urd-31 and recommended package of practices applied. The variety showed better branching, comparatively more number of pods per plant. This variety was not infected with yellow vein mosaic virus disease. More number of pods observed under CFLD plots also ascribed due to effective sucking pest management through spray of Dimethoate 30 EC 1.0 litre /ha or Imidacloprid 17.8 SL 250 $\mathrm{ml} / \mathrm{ha}$. Similarly, yield enhancement in blackgram crop though cluster front line demonstrations were documented by Bairwa et al., (2013), Dwivedi et al., (2018) and Saikia et al., (2018).

A perusal of data (Table 2) further reveals that values for extension gap ranged from 1.58 to $3.10 \mathrm{q} \mathrm{ha}^{-1}$ with a mean value of $2.36 \mathrm{q}$ $\mathrm{ha}^{-1}$ during the period of demonstration which emphasizes the need for transferring the feasible improved technologies among farmers to bridge the extension yield gap. Technology gap which implies researchable issues for realization of potential yield ranged from 4.65 to $9.26 \mathrm{q} \mathrm{ha}^{-1}$, with a mean of 6.63 $\mathrm{q} \mathrm{ha}{ }^{-1}$ during three years of demonstration. Yearly variation in the technology gap might be due to dissimilarity in soil fertility status, rainfall distribution as well as change in location of demonstration sites. Higher technological gap observed during kharif 2018 might be due to yield losses caused by heavy rainfall at maturity phase of the crop.

Technology index shows the feasibility of evolved technology at the farmer's field and lower the value of technology index more is the feasibility of the technology (Katare et al., 2011).

Technology index in the present study varied between 31.0 to 61.73 per cent and averaged 44.20 per cent. Variation in technology index during three seasons might be attributed to dissimilarity in the rainfall pattern and soil condition (Fig. 1). 
Economic indicators i.e. gross cost of cultivation, gross returns, net returns and B:C ratio of front line demonstrations are presented in Table 3. The gross cost of cultivation for blackgram cultivation under demonstrated practice ranged from Rs. 17849 to 20675 ha $^{-1}$ with a mean value of Rs. 19553 ha $^{-1}$ against local check where it ranged from Rs. 13650 to $17380 \mathrm{ha}^{-1}$ with an average of Rs. $15787 \mathrm{ha}^{-1}$. The data clearly shows that demonstrated technologies provided substantially higher net returns than local check i.e. farmers practice during all the years of demonstration. FLD practice on three years average, fetched net returns of Rs $21345 \mathrm{ha}^{-1}$ with $\mathrm{B}$ : $\mathrm{C}$ ratio of 2.09 , higher in comparison to local practice (Rs $13627 \mathrm{ha}^{-1}$, B:C ratio 1.86). An average additional returns of Rs.11484 $\mathrm{ha}^{-1}$ was obtained under demonstrated technologies with incremental $B$ : C ratio of 3.05 which might be attributed to yield enhancement under demonstration with least additional cost. Higher cost benefit ratio and additional returns clearly shows that demonstrated techniques were found cost effective \& feasible for yield enhancement of blackgram on farmer's fields. Farmer's were also found highly convinced with the technological interventions due to higher economic returns with least additional investment and management practices. The variation in cost benefit ratio during different years might be due to variation in yield performance and input output cost in that particular year.

\section{Reasons of low yield of blackgram at farmer's fields}

Use of old varieties seeds with yellow vein mosaic incidence, use of very high seed rate resulting in improper plant geometry, no practice of seed treatment and inadequate use of fertilizers, inadequate weed management and inadequate protection against sucking pests and diseases are major reasons for low yields of blackgram on farmers fields in the district.

Table.1 Technological gap analysis for CFLD on Blackgram

\begin{tabular}{|c|c|c|}
\hline Technological point & Existing Farmer's practice & Recommended practice \\
\hline Variety & Variety T-9, Local & Variety PU-31 \\
\hline Seed rate & $20-25 \mathrm{~kg} / \mathrm{ha}$ & $15-20 \mathrm{~kg} / \mathrm{ha}$ \\
\hline Seed treatment & $\begin{array}{l}30 \% \text { farmers treat the seeds with } \\
\text { fungicide like carbendazim }\end{array}$ & $\begin{array}{l}\text { Seed treatment with carbendazim 50WP @ } \\
2.0 \mathrm{~g} / \mathrm{kg} \text { seed and inoculation with } \\
\text { Rhizobium and PSB cultures }\end{array}$ \\
\hline Soil treatment & No soil treatment & $\begin{array}{l}\text { Soil treatment by Trichoderma viridie @ } \\
2.5 \mathrm{~kg} / \mathrm{ha} \text { (mixed with } 20-25 \mathrm{~kg} \text { FYM) }\end{array}$ \\
\hline Crop geometry & Sowing crops in $22.5 \mathrm{~cm}$ rows & Sowing crops in $30 \mathrm{~cm}$ rows \\
\hline Fertilizer application & $\begin{array}{l}\text { Majority of farmers did not apply any } \\
\text { fertilizer }\end{array}$ & $\begin{array}{l}\text { Fertilizer based on STR or Recommended } \\
\text { doses of NP (20:40 kg/ha) as basal, zinc } \\
\text { sulphate @ } 20-25 \mathrm{~kg} \text { and sulphur } 40 \mathrm{~kg} / \mathrm{ha}\end{array}$ \\
\hline Weed management & $\begin{array}{l}\text { No or injudicious use of herbicides } \\
\text { available in market }\end{array}$ & $\begin{array}{l}\text { Application of Imizathapyr 10SL @ } 55 \mathrm{ml} \\
\text { ai/ha at 15-20 DAS and hand weeding as } \\
\text { per need }\end{array}$ \\
\hline $\begin{array}{l}\text { Insect-pest } \\
\text { management }\end{array}$ & $\begin{array}{l}\text { No use of insecticides for sucking } \\
\text { pests or indiscriminate use of } \\
\text { insecticides }\end{array}$ & $\begin{array}{l}\text { Spray of Dimethoate } 30 \mathrm{EC} 1.0 \text { litre /ha or } \\
\text { Imidacloprid } 17.8 \mathrm{SL} 300 \mathrm{ml} / \mathrm{ha} \text { for } \\
\text { sucking pest }\end{array}$ \\
\hline
\end{tabular}


Table.2 Impact of Front Line Demonstrations (FLD) on yield performance of blacklgam

\begin{tabular}{|c|c|c|c|c|c|c|c|c|}
\hline \multirow[t]{2}{*}{ Season \& Year } & \multirow{2}{*}{$\begin{array}{l}\text { No. } \\
\text { of } \\
\text { FLD }\end{array}$} & \multirow{2}{*}{$\begin{array}{c}\text { Area } \\
\text { of FLD } \\
\text { (ha) }\end{array}$} & \multicolumn{2}{|c|}{ Yield (q/ha) } & \multirow{2}{*}{$\begin{array}{c}\% \\
\text { increase } \\
\text { over FP }\end{array}$} & \multirow{2}{*}{$\begin{array}{l}\text { Exten- } \\
\text { sion } \\
\text { Gap } \\
\text { (q/ha) }\end{array}$} & \multirow{2}{*}{$\begin{array}{c}\text { Technology } \\
\text { Gap } \\
\text { (q/ha) }\end{array}$} & \multirow{2}{*}{$\begin{array}{c}\text { Techno- } \\
\text { logy } \\
\text { Index } \\
(\%)\end{array}$} \\
\hline & & & IT & FP & & & & \\
\hline Kharif 2016 & 60 & 30.0 & 9.02 & 6.62 & 36.25 & 2.40 & 5.98 & 39.87 \\
\hline Kharif 2017 & 75 & 30.0 & 10.35 & 7.25 & 41.33 & 3.10 & 4.65 & 31.00 \\
\hline Kharif 2018 & 125 & 50.0 & 5.74 & 4.16 & 38.15 & 1.58 & 9.26 & 61.73 \\
\hline \multicolumn{3}{|c|}{ Mean } & 8.37 & 6.01 & 39.27 & 2.36 & 6.63 & 44.20 \\
\hline
\end{tabular}

IT- Improved technology

FP- Farmer's local practice

Table.3 Impact of Front Line Demonstration on economic indicators of blackgram

\begin{tabular}{|c|c|c|c|c|c|c|c|c|c|c|}
\hline \multirow[t]{2}{*}{$\begin{array}{l}\text { Season \& } \\
\text { Year }\end{array}$} & \multicolumn{2}{|c|}{$\begin{array}{l}\text { Gross cost of } \\
\text { cultivation } \\
\text { (Rs./ha) }\end{array}$} & \multicolumn{2}{|c|}{$\begin{array}{l}\text { Gross Return } \\
\text { (Rs./ha) }\end{array}$} & \multicolumn{2}{|c|}{$\begin{array}{l}\text { Net Returns } \\
\text { (Rs./ha) }\end{array}$} & \multicolumn{2}{|c|}{$\begin{array}{l}\mathrm{B}: \mathrm{C} \\
\text { ratio }\end{array}$} & \multirow[t]{2}{*}{$\begin{array}{c}\text { Additional } \\
\text { Returns } \\
\text { (Rs./ha) }\end{array}$} & \multirow[t]{2}{*}{$\begin{array}{c}\text { Incremental } \\
\text { B:C ratio }\end{array}$} \\
\hline & IT & FP & IT & FP & IT & FP & IT & FP & & \\
\hline $\begin{array}{c}\text { Kharif } \\
2016\end{array}$ & 20135 & 17380 & 56375 & 41375 & 36240 & 23995 & 2.80 & 2.38 & 15000 & 5.44 \\
\hline $\begin{array}{c}\text { Kharif } \\
2017\end{array}$ & 20675 & 16330 & 41400 & 29000 & 20725 & 12670 & 2.00 & 1.78 & 12400 & 2.85 \\
\hline $\begin{array}{c}\text { Kharif } \\
2018\end{array}$ & 17849 & 13650 & 24919 & 17867 & 7070 & 4217 & 1.40 & 1.31 & 7052 & 1.68 \\
\hline Mean & 19553 & 15787 & 40898 & 29414 & 21345 & 13627 & 2.09 & 1.86 & 11484 & 3.05 \\
\hline
\end{tabular}

Fig.1 Changing scenario of blackgram cultivation in Kota district during 2014-2018

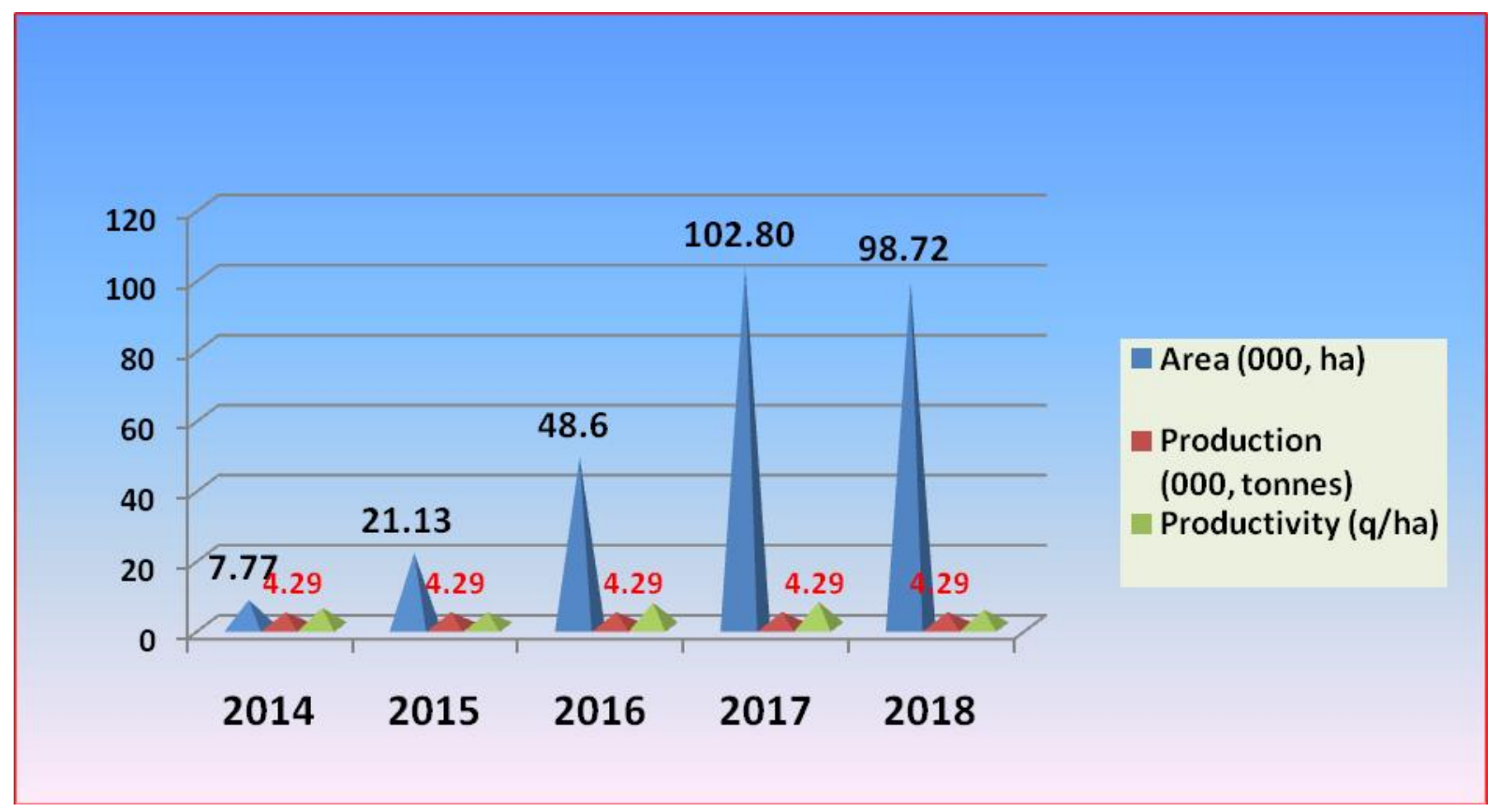




\section{Impact of front line demonstrations}

Earlier years, incidence of YMV was the major constraint for urdbean cultivation, therefore, the area under blackgram cultivation remained less than 25 thousand ha in the district. Soybean has been a major kharif crop of the district which was cultivated in 194.3 thousand ha area during kharif 2015, however, productivity of soybean remained below $12.5 \mathrm{q} \mathrm{ha}^{-1}$ due to unfavorable rainfall during the study period. Introduction of short duration, high yielding and YMV resistant variety Pant Urd-31 of urd bean through front line demonstrations and with the support of line department of agriculture, the area of blackgram has increased from 7.78 thousand ha in kharif 2013 to 1.028 lakh ha in kharif 2017 (Anon., 2017). The performance of PU-31 variety was found quite satisfactory as it showed YMV resistance, pod matured at one time and yield was found on an average 25-40 per cent higher over local check T-9. This variety of blackgram became so popular that remarkable area of soybean has been replaced by blackgram cultivation. Quality seed production of $360 \mathrm{q}$ of variety Pant Urd-31 was also taken at KVK farm and farmers' field under pulse seed hub, which add in the rapid horizontal expansion of the variety.

In conclusion, the results of cluster front line demonstrations presented clearly indicates that the blackgram productivity can be enhanced to the magnitude of 36.2 to 41.3 per cent on farmers fields with the popularization of improved production technologies on farmers fields in Kota district. There is the need of transfer of adoptable technologies suitable for enhancing the productivity of blackgram crop through conducting such demonstrations. Technological and extension gaps can be bridged by popularizing package of practices with emphasis on improved variety seed, seed treatment, integration of bio-fertilizer inoculants, use of recommended fertilizers, weed management practices and integrated insect-pest management techniques. It is concluded that the CFLD programme is a successful tool in enhancing the production and productivity of blackgram crop through changing the knowledge, attitude and skill of farmers. Blackgram yield as well as economic returns at farmers fields enhanced through adoption of Pant urd-31 variety along with improved recommended practices.

\section{Acknowledgement}

The authors are thankful to the Director Extension, Agriculture University, Kota and Director, ATARI, Zone II, Jodhpur (ICAR) for providing financial assistance towards conducting these front line demonstrations.

\section{References}

Anonymous (2017). Rajasthan Agricultural Statistics At a glance, Govt. of Rajasthan. 2016-17 PP -79

Anonymous (2018). Land records, Revenue department, Govt. of Rajasthan.

Bairwa, R. K., S. R. Verma, K. Chayal and N. L. Meena. (2013). Popularization of Improved Black gram Production Technology through Front line demonstration in humid southern plain of Rajasthan, Indian Journal of Extension Education and R.D. 21: 97101.

Choudhary, B. N. 1999. Krishi Vigyan Kendra - A guide for KVK managers. Publication, Division of Agricultural Extension, ICAR. pp 73-78.

Dwivedi, R. K. , B. K. Tiwari and K. S. Baghel. (2018). Role of cluster front line demonstrations in enhancement of blackgram (Vigna mungo) production. Plant Archives 18 (1) : 1088-1090.

Katare, S., S.K. Pandey, and M. Mustafa, 
.2011. Yield gap analysis of Rapeseed-mustard through front line demonstrations. Agric. Update, 6(2): 5-7.

Saikia, Nabadeep, Kapil Nath and Pulakabha Chowdhury (2018). Impact of cluster frontline demonstrations on popularization of blackgram var. PU 31 in Cachar district of Barak Valley region of Assam. Journal of Pharmacognosy and Phytochemistry 2018; 7(4): 940-942.
Samui, S K, S. Maitra, D. K. Roy, A. K. Mondal and D. Sahu .2000. Evaluation of front line demonstration on groundnut. Journal of Indian Society of Costal Agricultural Research 18(2): 180-306.

Singh, D.P., B.B. Singh and Sanjeev Gupta.2015. Development of Pant Urd 31: A high yielding and yellow mosaic disease resistant variety of blackgram. Journal of Food Legumes 28(1): 1-4.

\section{How to cite this article:}

Sharma, K.M., M.C. Goyal Mahendra Singh, and Anil Kumar Sharma. 2019. Impact of Frontline Demonstrations on Productivity and Profitability of Blackgram (Vigna mungo) in Kota District of Rajasthan, India. Int.J.Curr.Microbiol.App.Sci. 8(04): 871-877.

doi: https://doi.org/10.20546/ijcmas.2019.804.098 